UDC 336

DOI: $10.15673 /$ fie.v12i3.1814

\author{
Kalaman 0. \\ Ph. D., Associate Professor \\ Department of Management and Logistics \\ E-mail: kalaman.olga@gmail.com \\ ORCID ID: 0000-0001-5586-7654
}

\author{
Purtskhvanidze 0. \\ Ph. D., Associate Professor \\ Department of Management and Logistics \\ E-mail: olga.kenga@gmail.com \\ ORCID ID: 0000-0002-3111-7274
}

\author{
Levchuk Yu. \\ Assistant \\ Department of Management and Logistics \\ Odessa National Academy of Food Technologies \\ Kanatna str., 112 Odesa, Ukraine, 65039 \\ E-mail: Levchyk_onaft@ukr.net \\ ORCID ID: 0000-0001- 7417-2866
}

\title{
METHODOLOGY FORMATION OF ENTERPRISE FINANCIAL STRATEGY ON THE BASIS OF EXISTING MODELS ANALYSIS
}

The article analyzes the basic existing methodological approaches to modeling the financial strategy of the enterprise. It has been noted that the Du Pont model was the first to be developed, based on a modified factor analysis in the direction of key reporting indicators. The main idea of the methodology of "sustainable growth" is in modeling the possible growth rate of the enterprise while maintaining financial stability. T.V. Heniberg, N.A. Ivanova, O.V. Polyakova proposed a combined approach based on a combination of the Du Pont model and the methodology of "sustainable growth". The Franchon-Romane matrix model is quite popular. M.L. Dorofeev offers a three-dimensional system for evaluating financial decisions and introduces a comprehensive indicator of CRA as a variable component of the rating matrix. One of the most popular and used is the ADL/LC model of A.D.Little. As a result of the study, a scheme for forming the financial strategy of the winery according to an improved methodology was proposed. It formed the basis for formalizing the requirements for the financial strategy of wineries and presenting the stages of formation for it.

Key words: strategy, financial strategy, enterprise functioning, financial resources, methodology of strategic modeling, matrix of financial strategies.

This work is licensed under a Creative Commons Attribution 4.0 International License http://creativecommons.org/licenses/by/4.0/

Statement of the problem and its connection with important scientific and practical tasks. Currently, more and more companies understand the need for effective management, based on the forecast of fluctuations of external factors, the dynamics of the industry growth and the company itself in particular. Financial strategy is a tool for effective management, which allows companies to develop, move towards goals and adapt to changes occurring at the micro and macro levels. The most important factor influencing the activities of the enterprise is the speed and dynamics of change of financial factors in the external environment. Changing macroeconomic indicators, market conditions, technological progress, government reforms limit the effectiveness of management decisions. In this situation, a well-designed financial strategy, which provides for possible changes in external factors, gives the company a powerful lever for the coordinated activities of the entire enterprise to achieve the main goal.

The stages of the life cycle of the researched enterprise, which influence the result of formation of financial strategy, deserve special attention. According to this cycle, the company during its existence goes through a series of successive stages - from inception to exit from the market. At each stage, it is characterized by certain parameters that show its current state and prospects. The financial strategy enables the development of the enterprise due to the timely adaptation of activities to future changes.

The analysis of the latest publications on the problems. Today it has been proven that financial strategy in the strategic management of financial activities of enterprises is a key tool. The main aspects of development and implementation of the financial strategy of the enterprise are revealed in the scientific works of such scientists as: Blank I.O., Porter M., Ansoff I., Ivanyuta S.M., Grinyov A.V. and others. However, the lack of work on the systematization of the developed methods leads to the choice of existing ones, which has its shortcomings and will bring negative trends in the process of forming the overall strategy of the studied enterprise.

Forming of the aims of the research. The current situation in the scientific environment concerning studying the formation of financial strategy can have a 
detrimental effect on the process of effective operation of the enterprise. Therefore, we consider it necessary to analyze and systematize the existing financial strategies, identify their strengths and weaknesses, and propose a scheme for forming the financial strategy of the winery according to an improved methodology.

Giving an account of the main results and their substantiation. The most important problem today for the development of the theory of strategic financial management of the enterprise is to clarify the methodology and set of targets on the basis of which it is possible to correctly form and implement a financial strategy. Targets should objectively characterize the quality of financial management for a particular period of operation of the enterprise. Most of the domestic methods of forming a financial strategy is based on the general concept of enterprise management, and is an attempt to improve and adapt to domestic conditions of economic activity already existing in foreign economic practice models of financial management. The most mentioned basic foreign methodological approaches to the formalization and modeling of strategic financial management are: the Du Pont model, the concept of "sustainable growth" from Boston Consulting Group (BCG), the ADL / LC strategic matrix, the Franchon-Romane matrix model.

The Du Pont model is chronologically the first methodology of strategic financial modeling. Built on the basis of a modified factor analysis of basic financial and operational reporting indicators, the Du Pont model is based on the assessment of effective resource management influence of the studied enterprise on the dynamics

of ROE. In formalized form, the model is expanded:

$$
\mathrm{ROE}=(\mathrm{SI} / \mathrm{SR}) *(\mathrm{SR} / \mathrm{A}) *(\mathrm{~A} / \mathrm{E}),
$$

where ROE - return on equity,

SI - profit from sales,

$\mathrm{SR}$ - sales revenue,

A - total assets,

E - equity [1]

According to the model, setting the target financial indicator at the required level of ROE, you can predict and control the acceptable ranges of the indicator group (return on sales, asset turnover, financial dependence). The Du Pont model is useful to use as an opera- tional tool to control the current stability of the enterprise; to use in forecasting and strategic financial planning it is expedient only in the part of modeling of admissible level of financial risk at target parameter of ROE and sales, speed of turnover of assets. As the basis of financial strategy, despite the simplicity of analysis and linking indicators to reporting forms, it's rarely used because of ignoring the basic criteria - industry and individual specifics of the enterprise, the stages of its life cycle and the dynamism of environmental factors.

The concept of "sustainable growth rate" from BCG was developed and practically tested by a relevant consulting firm for strategic financial management of enterprises. The essence of this concept is to model the maximum allowable growth rate of economic activity (revenue) of the enterprise while maintaining financial stability. In other words, the allowable growth rate of turnover provided by own financial resources is analyzed. At the same time there is no change in the financial policy of the investigated enterprise in terms of increasing the indicators of financial leverage or additional issue of shares. In the basic version, the rate of sustainable growth is calculated by the formula:

$$
\mathrm{SGR}=\operatorname{ROE} *(1-\mathrm{b}),
$$

where SGR - rate of steady increase in revenue, b - reinvestment ratio of net profit [2].

Then the steady rate of increase in revenue is compared with the actual and forecast and determines the nature of the financial stability of the investigated enterprise and the level of security of the actual and planned increase in revenue. Later in the literature there were repeated attempts to improve and expand the basic methodological approach in order to adapt the methodology of sustainable growth to build and choose a financial strategy which is designed to solve strategic problems in managing the researched enterprise, namely: formation of specific financial goals, monitoring their achievement, analysis of actually obtained deviations for management decisions. Scientists T.V. Heniberg, N.A. Ivanova and O.V. Polyakova proposed a combined approach based on a combination of the Du Pont model and the method of calculating the rate of steady increase in revenue (Fig. 1).

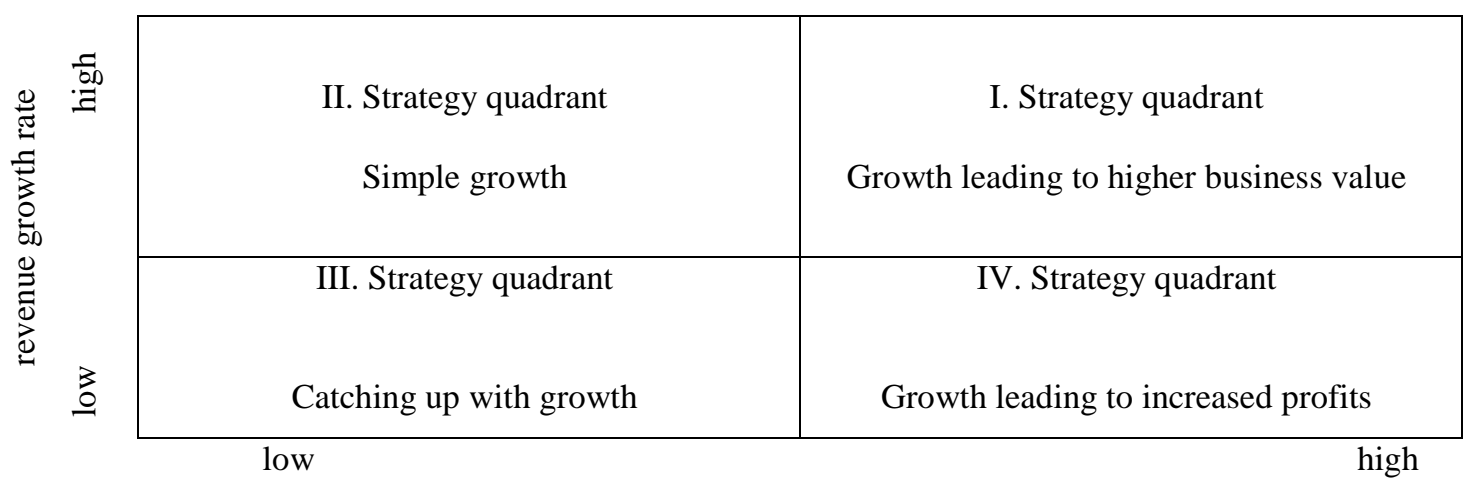

funding growth rate

Fig. 1. Methodology for developing the financial strategy of the researched enterprise in terms of financing policy by T.V. Heniberg, N.A. Ivanova and O.V. Polyakova [3] 
According to the authors, the rate of steady growth is the only possible rate of increase in sales with the constancy of the considered 4 coefficients of the $\mathrm{Du}$ Pont factor model: return on sales, return on assets, level of financial leverage and savings rates. The formula for the rate of sustainable growth takes the form:

$$
\mathrm{g}=\mathrm{RM} * \mathrm{AT} * \mathrm{FL} * \mathrm{R}=\mathrm{ROE} * \mathrm{R},
$$

where RM - return on sales,

JSC - asset turnover,

FL - financial leverage,

$\mathrm{R}$ - rate of capital accumulation (reinvestment of profits).

Based on the analysis of the actual and projected growth rate of funding (product of FL and $\mathrm{R}$ ) and revenue growth rate (product of RM and JSC) in comparison with industry averages, the nature of revenue growth is analyzed and recommendations are made on the choice of financing policy. [3].

Based on the actual and projected location of the financial strategy in a certain quadrant, these authors offer a set of management recommendations for investing available resources of the enterprise and raising borrowed capital to finance economic growth. Using this technique, it is possible to assess and control financial risks that in- crease with a negative strategic spread, exceeding the actual growth rate of revenue over sustainable. Despite the existing advantages of this technique, such as simplicity of analysis, linking the analyzed indicators to reporting forms, certainty in terms of policy of financing operating activities as part of the overall strategy, this approach can not serve as a universal methodological tool for financial strategy of the enterprise. The authors focus exclusively on current operating results and their possible impact on the strategic position in the future, ignoring investments in capital assets and R\&D, which is unacceptable for such industries as winemaking, where the investment process is one of the important factors in competitiveness and potential future economic benefits of the enterprise. Other shortcomings are: narrowness in terms of recommendations for choosing a financial strategy, which are to identify sources of funding and areas of financial investment. This ignores many other important components of financial strategy, environmental conditions and prerequisites, their dynamism, business profile and stage of the life cycle.

Another popular method in the economic literature for the formation and definition of the type of possible financial strategy for the studied enterprise is the Franchon-Romane matrix model (Fig. 2).

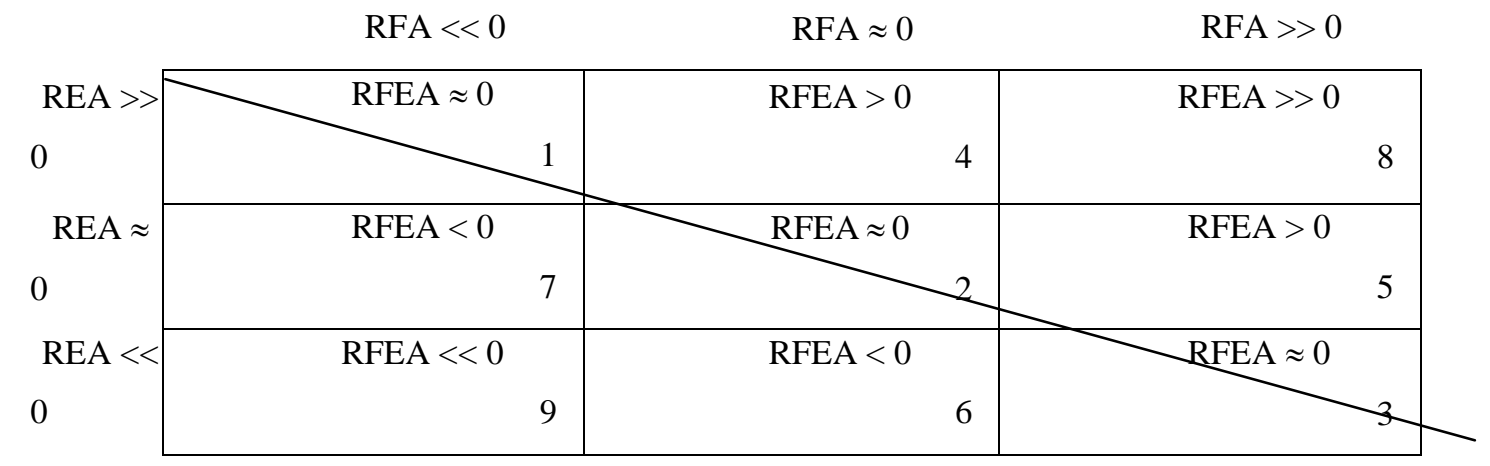

Fig. 2. Matrix of enterprises finding financial strategies by J. Franchon and I. Romane [4]

In the basic version, these models are based on the analysis of 3 indicators of current activity:

- results of economic activity (REA): REA = profit before taxes less changes in financial and operational needs and production investments and the addition of property sales;

- results of financial activities (RFA): RFA = change in borrowed funds less financial expenses on borrowed funds, income tax and (dividends + other incomes from financial activities);

- results of financial and economic activities (RFEA): RFEA = REA + RFA.

Relying on forecast or actual indicators, a matrix of a possible set of financial strategies of the studied enterprises is formed. In it values of RFA are shown horizontally, and RGD are shown vertically. Thus, the matrix contains 9 quadrants that characterize a certain type of financial strategy of the studied enterprise. According to V.B. Akulov, the space above the diagonal - a zone for analytical indicators is relatively positive. Below the diagonal - on the contrary - respectively, the zone of defi- cits and failures. It is important that the 4th, 8th, 5th quadrants characterizes the researched enterprise as one that creates liquid funds (some of their excess). In turn, the 7 th, 6th, 9th quadrants show the researched enterprise consumes liquid funds (there is a certain deficit of them). The horizontal increase in RFA reflects the increase in borrowed funds from the studied enterprise, as there is a tendency to increase RFA. Vertical REA shows that the implementation of a certain investment project, because it often explains the decrease in RGD [5].

Based on the analysis of the actual and forecast location of the enterprise in specific quadrants of the matrix, these authors recommend a set of actions in terms of resource management, highlighting such aspects as liquidity management and accounts payable / accounts receivable. The advantage of this method of financial strategy is a comprehensive description of the use of assets and liabilities in terms of financial and current (operating) activities. The most significant disadvantage of the Franchon-Romane methodological approach is the excessive aggregation of the analyzed indicators, consideration 
of operating and investment activities together complicates the possible analysis of the reasons for the change in RGD, as in the case of investment activities there are delayed positive FL-effects, which strengthen strategic positioning of the enterprise and the potential of added value creation. The lack of detail of cost items, cause, effect and analysis of the dynamics of financial statements complicates any real conclusions about the reasons for the actual movement of the enterprise between the quadrants of the matrix, and the lack of tools to adapt the tools to industry and functional specifics, ignoring the influence of the factors make it impossible to apply the given, matrix within the main functionality of financial strategy: goal setting and development. Thus, the analyzed matrix helps to assess only the overall actual financial position of the enterprise without reference to the overall strategy and factors.

The methodological approach, which is based on the construction of a matrix of financial strategies on the type of Franchon-Romane, is often improved and adapted to specific business entities in the economic literature. To some extent, the method of constructing matrices of financial strategies on the type of Franchon-Roman was improved by M.L. Dorofeev (Fig. 3).

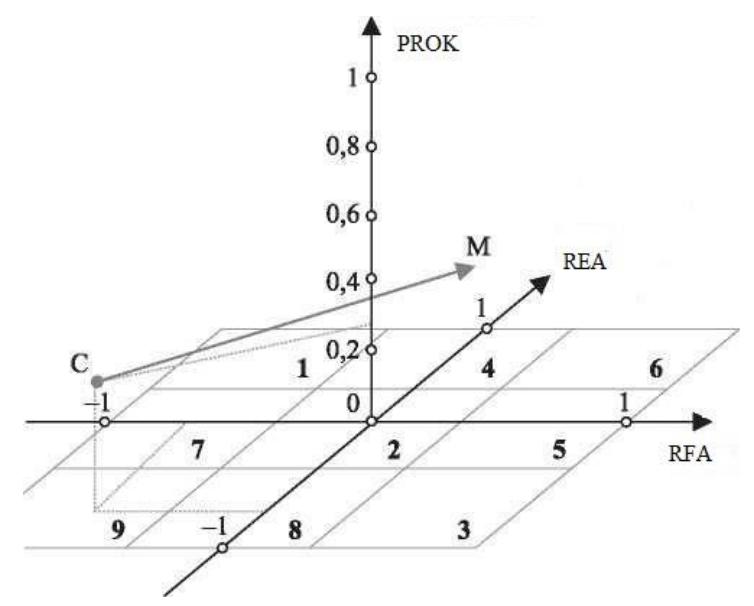

Fig. 3. The matrix of rating financial strategy of M.L. Dorofeev [6]

The author proposes a three-dimensional system of rating matrix for evaluating financial decisions of the enterprise. The concept of a complex indicator of PROC is introduced, which is a variable component of the rating matrix and is a formalized integrated result of combining analytical results of different financial and non-financial indicators, the composition of which is determined by experts depending on the specifics of the analyzed enterprise [7]. The introduction of a rating assessment of the financial condition of the studied enterprise, according to the author, gives the strategic matrix high versatility and effectiveness in corporate finance management. This matrix also includes a vector of financial strategies (CM), which reflects the trend of changes in the indicators of the analyzed enterprise in terms of full implementation of strategic financial goals. The CM vector consists of an infinite number of points in the coordinates of the matrix of the rating financial strategy. It starts at point $\mathrm{C}$ and tends to point $\mathrm{M}$. Point $\mathrm{C}$ reflects the actual financial condition of the investigated enterprise. Point $M$ represents the target state of the studied enterprise, which corresponds to the implementation of the financial strategy. All intermediate points of the vector reflect the transitional financial condition of the enterprise as it moves to the implementation of the financial strategy of the studied enterprise.

Methodological improvement of the basic tools of the Franchon-Romance matrix eliminates some inherent shortcomings of this technique, in particular, the author introduces purposeful criteria of strategic financial management, tries to take into account economic and managerial specifics of the enterprise by introducing the index of the enterprise rating which is a substantial progress in adaptation of this method on the third axis. However, not all basic shortcomings have been overcome: the rating indicator is subjective and the choice of analyzed financial indicators is ambiguous from the standpoint of strategic financial analysis.

One of the most common and potentially suitable for methodological improvement of tools for the formation of financial strategy of the studied enterprise is the model of strategic management AD Little ADL/LC [8]. According to the basic theoretical postulates of the ADL/LC model, the strategic positioning of an enterprise is based on determining the final competitive position of its individual types of business depending on external preconditions, primarily industry and technological factors, the life cycle stage of the enterprise and its products. Determining the strategic financial position of the studied enterprise is based on two criteria - the stage of the life cycle of the business and the competitive position of these businesses in their industry (dominant, strong, visible, strong or weak). Each area of activity of the researched enterprise is analyzed separately in order to find out the stage of development of the industry and the competitive position within it. Thus, the strategic matrix of ADL contains 20 components, which are formed by 4 stages of the life cycle of the studied industry and 5 possible competitive positions. Stages of the life cycle of the studied industry in the matrix are indicated on the $\mathrm{Y}$ axis. 
They are characterized by the following factors: the dynamics of sales revenue of products (goods, services) of a particular enterprise, predictability of sales revenue growth, product line dynamics, number of competitors and market share as a percentage of total revenue, the peculiarity of the distribution of the market, the consistency of consumers, the presence of starting barriers, the applied technology of products sale.

Competitive position in the industry is often determined by the percentage of the market in revenue or consumers, in the ADL matrix it's indicated by the $\mathrm{X}$ axis: leading position - control of more than $50 \%$ of the industry market; strong position - distance from the near- est competitor in terms of market share by 1.5 times; noticeable - leaders of weakly concentrated industries, large competitors are at about the same level $(10-25 \%$ of the industry); strong - specialization in a narrow and relatively secure niche; weak - characterized by an uncompetitive position in the industry. In the basic version, the concept of ADL was designed not so much to build a financial strategy for a particular enterprise as a whole, but for strategic analysis and planning in terms of activities (Fig. 4). The main indicator used to balance the business portfolio and reflect the contribution of each activity to the success of the enterprise is the RONA-graph [8].

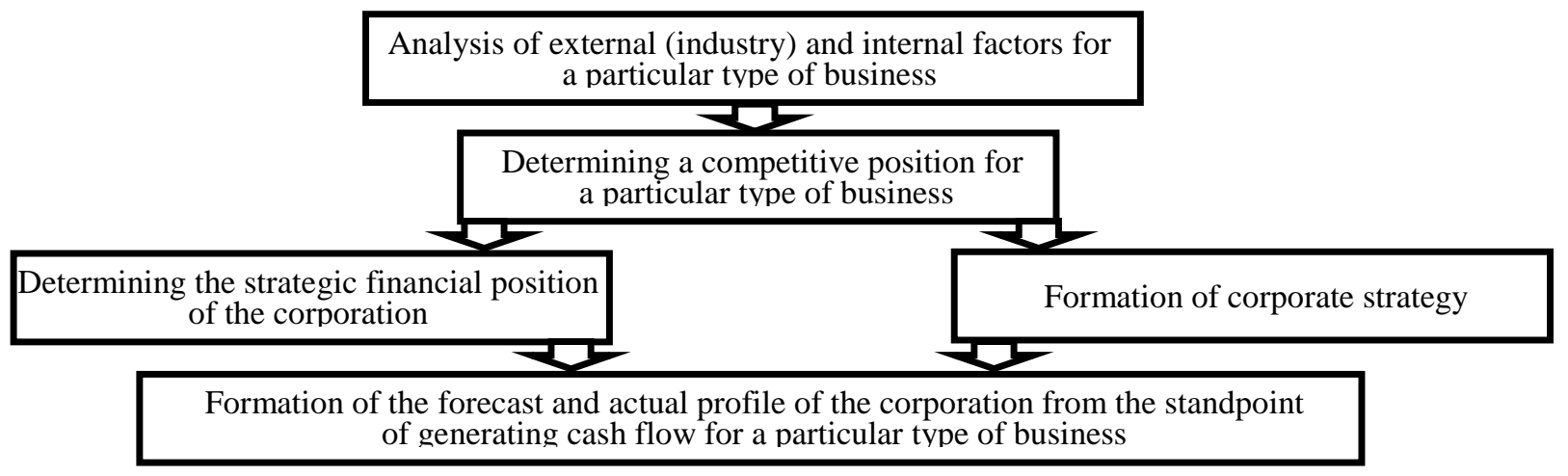

Fig. 4. Algorithm for forming the financial strategy of the researched enterprise according to the ADL/LC method*

* developed by the author

The graph is a matrix composed of two parameters - the relative RONA (\%) and the level of reinvestment, which schematically shows the efficiency of each business in these coordinates:

RONA = NI / (FA + CA - CL), (4)

where by specific type of business:

NI - net income,

FA - non-current assets,

CA - current assets,

CL - short-term liabilities.

The level of reinvestment (\%), which is also called "internal redistribution of cash (Internal Deployment)", is defined by the authors as the share of enterprise funds reinvested in this area of activity (\%), ie

$\mathrm{ID}=\Delta \mathrm{A} / \Delta(\mathrm{NI}-\mathrm{T}+\mathrm{Am})(5)$

where $\mathrm{A}$ is the total value of assets at the end of the period,

Am - accrued depreciation for the period

NI - net income,

$\mathrm{T}$ - taxes,

A - change in the indicator for the analyzed peri-

od.

Thus, the actual profile of the enterprise is formed from the standpoint of cash flow generation in each area of activity. The authors developed this approach for industries in which the product life cycle is short and the goals may not be achieved if the necessary financial strategy is not applied in time, as well as for highly diversified conglomerate enterprises whose prod- ucts are represented in various specific unrelated sectors of the economy. Despite the more specific nature of the target indicator of financial efficiency of the researched enterprise, the ADL/LC method is not deprived of its shortcomings from the standpoint of forming the financial strategy of the researched enterprise, as:

- aimed at analyzing the financial efficiency of a particular area of activity, rather than the strategy of the enterprise as a whole, so there is no mechanism for determining the purpose of the enterprise and assessing the effectiveness of its current activities;

- as a key criterion of financial efficiency, ratios based on the NI indicator "net income" are used, which does not take into account the volume of real capital investments, thus, the emphasis is only on current operating activities, which is unacceptable for high-tech and capital-intensive industries which have a long cycle of capital turnover; also the consequence of transformational changes of these indicators may well be a situation in which the direction of activity will be positively characterized in the built coordinate system, but the company gradually loses competitive potential in this area due to lagging behind competitors in terms of revenue growth or market share;

- the possible influence of the dynamics of key macroeconomic indicators in the regions of economic presence on the efficiency of current and future activities of the enterprise in these markets is not taken into account. 
Thus, the existing ADL/LC approach needs to be refined in terms of specifying the recommended tools for forming a financial strategy for the activities of the analyzed enterprise. Based on the shortcomings of the described methodological approaches to the formation of the financial strategy of the researched enterprise, it is important to propose a methodological approach that specifies the application of the ADL / LC methodology for the formation of the financial strategy of wineries.

Without rejecting in general the resource concept of management and the role of internal factors of competitiveness (possession of unique resources and abilities) in achieving strategic financial success of enterprises, it is necessary to hypothesize the dominant force of external factors in success, such as macroeconomic dynamics, life and technological cycles and industries, political and social factors, consequently this process of strategic goal-setting should be based on the method of deduction - from determining the general conditions and success factors to the formation of target financial indicators of long-term activity with the general logic of "outside-inside". Based on the ADL/LC methodology, a comparison of the quality of financial management of enterprises in one industry is possible when their strategic positions are comparable. Based on the strategic positions of the enterprise in specific industries, corporate and financial strategies are consistently formed (Fig. 5).

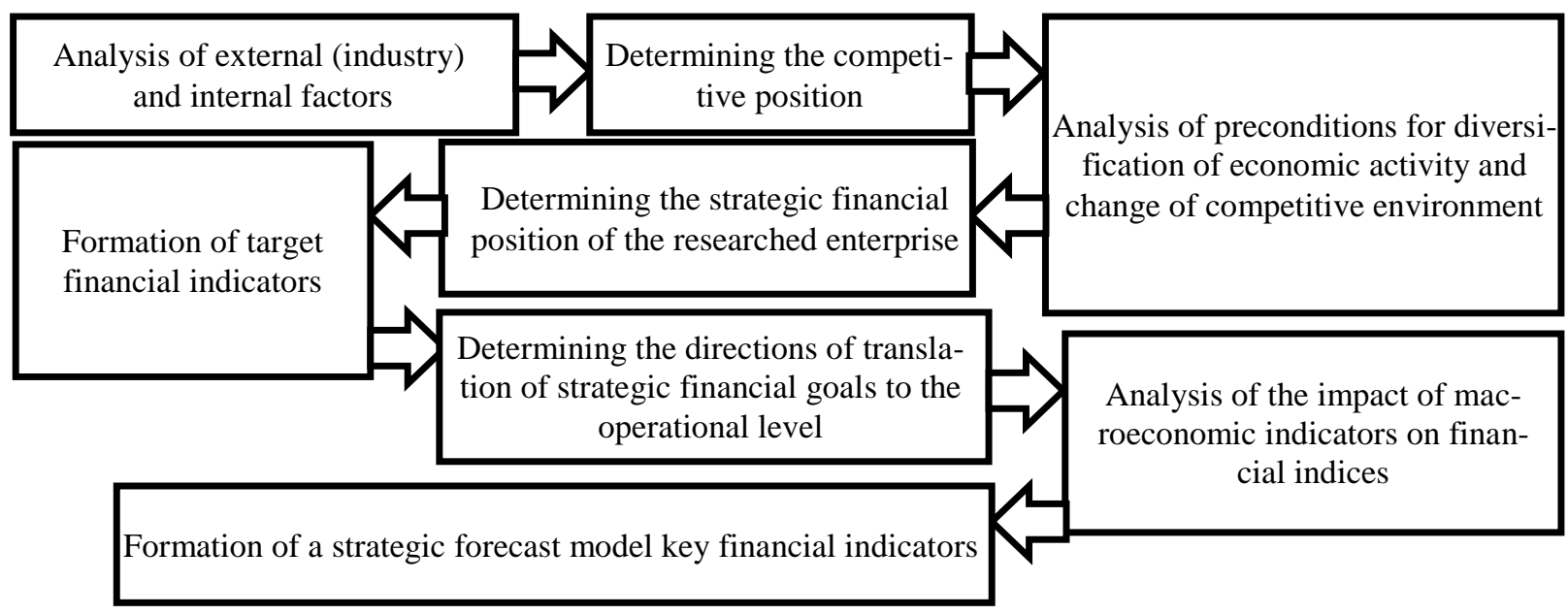

Fig. 5. The scheme of formation of financial strategy of the winery according to the improved technique* * developed by the author

Conclusions and prospects of the further investigations. Accordingly, with a significant difference in the strategic positions of enterprises in terms of industries, it is difficult to make a correct comparison of the effectiveness of financial management due to differences in the basic objectives of these enterprises.

We formalize the requirements for the financial strategy of wineries:

- should promote the implementation of the basic corporate strategy,

- should be the main tool for determining the purpose and assessing the effectiveness of economic activity of the winery,

- must take into account the specifics of the industry and the stage of its life cycle,

- the influence of external environmental factors, in particular, macroeconomic conditions should be taken into account in the implementation of the financial strategy by adjusting the significant indicators of economic activity. the winery:

Stages of formation of the financial strategy of

- determination of a strategic competitive position in the context of a certain area of activity based on the methodological approach ADL / LC,
- formation of the general corporate strategy on the basis of the methodological approach of ADL / LC, taking into account the analysis of preconditions for diversification of economic activity and change of the competitive environment,

- definition of a set of target financial indicators of activity taking into account specifics of winemaking, and also a stage of a life cycle and degree of diversification of the enterprise as a whole,

- definition of tools and channels for translation of strategic financial goals at the operational and tactical level,

- actual analysis of the impact of key macroeconomic indicators on the selected target financial performance indicators in the reporting periods to build dynamic forecast models,

- formation of a strategic forecast model of the dynamics of key financial indicators of economic activity.

Thus, the basic concept of ADL is supplemented and clarified by intermediate stages between the definition of the strategic financial position of the winery and the formation of its desired forecast profile. 


\section{References}

1. Bondarenko, M. D. (2014). Osoblyvist vykorystannia modeli DuPont pry analizi protsesu formuvannia rentabelnosti bankiv. Statystyka ta ekonomika, (4), 25-29.

2. Ivashkivsku, I. V., \& Zhyvotova, O. L. (2009). Indeks stiikosti zrostannia: empirychna aprobatsiia. Visnyk SPbU, (4), 3-29.

3. Heniberh, T. V., Ivanova, N. A., \& Poliakova, O. V. (2009). Sutnist ta metodychni osnovy rozrobky finansovoi stratehii firmy. Naukovi zapysky NHUEU, (4). Retrieved July 22, 2020, from https://nsuem.ru/science/publications/science_notes/2009_4/3.pdf

4. Sanina, N. V., \& Khurchak, Yu. S. (2015). Formuvannia bezpechnoi finansovoi stratehii rozvytku komertsiinoi orhanizatsii. Visnyk VDAU, (4 (47)), 260-262.

5. Vorobiov, A. V., \& Leontiev, V. Ye. Analiz vitchyznianykh metodolohichnykh pidkhodiv do rozrobky finansovoi stratehii pidpryiemstva, yaki peredbachaiut pobudovu finansovykh matryts. Suchasni tekhnolohii upravlinnia, (3 (39)). Retrieved July 22, 2020, from https://cyberleninka.ru/article/n/analiz-otechestvennyh-metodologicheskihpodhodov-k-razrabotke-finansovoy-strategii-predpriyatiya-predpolagayuschih-postroenie/viewer

6. Dorofeiev, M. L. (2010). Matrychni metody upravlinnia korporatyvnymy finansamy [dissertation of kand. ekon. nauk: 08.00.10, 08.00.13]. Moscow: REA im. H. V. Plekhanova.

7. Vorobiov, A. V. (2011). Vitchyzniani metodolohichni pidkhody do rozrobky finansovoi stratehii pidpryiemstva (henezys i analiz). Finansy i kredyt, (16 (448)), 20-27.

8. Yefremov, V. S. (1998). Stratehiia biznesu. Kontseptsii ta metody planuvannia. Moscow: «Fynpres».

9. Kalaman O., Savenko I., \& Dolynska O. (2019). Conceptual positions of enterprise strategy functioning. Food Industry Economics, 11(3), 50-58. doi: 10.15673/fie.v11i3.1461

10. Kalaman, O. B. (2020). Osnovni skladovi kontseptsii upravlinnia efektyvnistiu diialnosti pidpryiemstva. Biznes, innovatsii, menedzhment: problemy ta perspektyvy. Zb. tez dop. I Mizhnarod. nauk.-prakt. konf., Kyiv: KPI im. Ihoria Sikorskoho, Vyd-vo «Politekhnika», 44-45.

Received 2 August 2020

Approved 16 August 2020 Available in Internet 15.10.2020

Каламан О.Б.

кандидат экономических наук, доцент кафедра менеджмента и логистики E-mail: kalaman.olga@ gmail.com ORCID ID: 0000-0001-5586-7654

\author{
Левчук Ю.С. \\ старший преподаватель \\ кафедра менеджмента и логистики \\ Одесская национальная академия пищевых технологий \\ ул. Канатная, 112, г. Одесса, Украина, 65039 \\ E-mail: Levchyk_onaft@ukr.net \\ ORCID ID: 0000-0001-7417-2866
}

\section{МЕТОДОЛОГИЯ ФОРМИРОВАНИЯ ФИНАНСОВОЙ СТРАТЕГИИ ПРЕДПРИЯТИЯ НА ОСНОВЕ АНАЛИЗА СУЩЕСТВУЮЩИХ МОДЕЛЕЙ}

В статье подробно проанализированы базовые существующие методологические подходы к моделированию фринансовой стратегии предприятия. Общеизвестными и востребованными сегодня действующими предприятиями считают модель Du Pont, концепцию «темпов устойчивого прироста» от BCG, стратегическую матрицу ADL/LC, модель Франшона-Романе. Отмечено, что первой была разработана модель Du Pont, что в основе которой модифицированный факторный анализ в направлении ключевых отчетных показателей. Выявлено, что ее применяют как оперативный инструмент для контроля устойчивости исследуемого предприятия. В ходе исследования выявлены недостатки, которые заключаются в игнорировании отраслевой и индивидуальной специфики исследуемого предприятия, его стадии жизненного цикла и динамизма окружающих фракторов. Отмечено, что методология «темпов устойчивого прироста» давно разработана и успешно апробирована при формировании 
финансовой стратегии. Ее основная идея заключается в моделировании возможных темпов роста хозяйственной деятельности предприятия при условии сохранения финансовой устойчивости. Показано, что Т.В. Гениберг, Н.А. Иванова, А.В. Полякова предложили комбинированный подход, основанный на сочетании модели Du Pont и методологии «темпов устойчивого прироста». Выявлено, что достаточно популярна матричная модель Франшона-Романе. Указанны ее преимущества и недостатки для реализации в практике хозяйствования. В статье указано, что М. Л. Дорофеев в определенной степени усовершенствовал методику Франшона-Романе. Он предлагает трехмерную систему оценки финансовых решений исследуемого предприятия и вводит комплексный показатель ПРОК как переменную составляющую рейтинговой матрицы. Однако и в этой матрицы не все базовые недостатки были преодолены. Отмечено, что одним из наиболее популярных и применяемых для методологического совершенствования формирования фринансовой стратегии исследуемого предприятия является модель ADL/LC A.Д. Литтла. Замечено, что методика ADL/LC имеет также определенные недостатки, хотя ее целевой показатель является более конкретным. Поэтому, основываясь на ADL/LC по cтратегическим позициям исследуемого предприятия в определенных отраслях поэтапно создается фринансовая стратегии. В результате проведенного исследования была предложена схема формирования финансовой стратегии винодельческого предприятия по усовершенствованной методике. Она легла в основу формализации требований к финансовой стратегии винодельческих предприятия и представлению этапов формирования относительно нее.

Ключевые слова: стратегия, фринансовая стратегия, функционирования предприятия, фринансовые ресурсы, методология стратегического моделирования, матрица финансовых стратегий.

Каламан О.Б.

кандидат економічних наук, доцент кафедра менеджменту і логістики E-mail: kalaman.olga@ gmail.com ORCID ID: 0000-0001-5586-7654

Левчук Ю.С.

Пурцхванідзе О.В.

кандидат фрілософрьких наук, доцент кафедра менеджменту і логістики

E-mail: olga.kenga@gmail.com ORCID ID: 0000-0002-3111-7274

старший викладач

кафедра менеджменту та логістики

Одеська національна академія харчових технологій

вул. Канатна, 112, м. Одеса, Україна, 65039

E-mail: Levchyk_onaft@ukr.net

ORCID ID: 0000-0001- 7417-2866

\section{МЕТОДОЛОГІЯ ФОРМУВАННЯ ФІНАНСОВОЇ СТРАТЕГІЇ ПІДПРИЄМСТВА НА ОСНОВІ АНАЛІЗУ ІСНУЮЧИХ МОДЕЛЕЙ}

В статті докладно проаналізовані базові існуючі методологічні підходи до моделювання фрінансової стратегії підприємства. Загальновідомими та затребуваними сьогодні діючими підприємствами вважають модель Du Pont, концепцію «темпів сталого приросту» від BCG, стратегічну матрицю ADL/LC, модель Франшона-Романе. Зазначено, що першою була розроблена модель Du Pont, що в основі якої модифрікований фракторний аналіз в напрямі ключових звітних показників. Виявлено, що її застосовують як оперативний інструмент для контролю стійкості досліджуваного підприємства. Під час дослідження виявлені недоліки, які полягають у ігноруванні галузевої та індивідуальної специфіки досліджуваного підприємства, його стадії життєвого циклу і динамізму оточуючих фракторів. Зазначено, що методологія «темпів сталого приросту» давно розроблена і успішно апробована при формуванні фінансової стратегії. Ї̈ основна ідея полягає в моделюванні можливих темпів зростання господарської діяльності підприємства при умові збереження фінансової стійкості. Наведено, що Т.В. Геніберг, Н.А. Іванова, О.В. Полякова запропоновали комбінований підхід, заснований на поєднанні моделі Du Pont i методології «темпів сталого приросту». Виявлено, що достатньо популярною є матрична модель Франшона-Романе. Зазначені її переваги та недоліки для реалізації у практиці господарювання. В статті зазначено, що М. Л. Дорофеєв в певній мірі вдосконалив методику Франшона-Романе. Він пропонує тримірну систему оцінки фрінансових рішень досліджуваного підприємства та вводить комплексний показник ПРОК як змінну складову рейтингової матриці. Проте і у цій матриці не всі базові недоліки були подолані. Відмічене, що однією з найбільш популярних і застосовуваних для методологічного вдосконалення формування фінансової стратегії досліджуваного підприємства $є$ модель ADL/LC A.Д. Літтла. Зауважено, що методика ADL/LC має також певні недоліки, хоча її конкретний цільових показник $\epsilon$ більш конкретним. Тому, засновуючись на ADL/LC щодо стратегічних позицій досліджуваного підприємства в певних галузях поетапно створюється фрінансова стратегії. Як результат проведеного дослідження була запропонована схема формування фінансової стратегії виноробного підприємства за 
вдосконаленою методикою. Вона лягла в основу формалізації вимог до фрінансової стратегії виноробних підприємства та представленню етапів формування щодо неї.

Ключові слова: стратегія, фрінансова стратегія, функціонування підприємства, фрінансові ресурси, методологія стратегічного моделювання, матриця фінансових стратегій.

\section{Література}

1. Бондаренко М. Д. Особливість використання моделі DuPont при аналізі процесу формування рентабельності банків // Статистика та економіка. 2014. № 4. С. 25-29.

2. Івашківську І. В., Животова О. Л. Індекс стійкості зростання: емпірична апробація. Вісник СПбУ: Серія менеджмент. 2009. Вип. 4. С.3-29.

3. Геніберг Т. В., Іванова Н. А., Полякова О. В. Сутність та методичні основи розробки фінансової стратегії фірми // Наукові записки НГУЕУ. 2009. №4. URL: https://nsuem.ru/science/publications/science_notes/2009_4/3.pdf (дата звернення: 22.07.2020).

4. Саніна Н. В., Хурчак Ю. С. Формування безпечної фінансової стратегії розвитку комерційної організації // Вісник ВДАУ. 2015. № 4 (47). С. 260-262.

5. Воробйов А. В., Леонтьєв В. Є. Аналіз вітчизняних методологічних підходів до розробки фінансової стратегії підприємства, які передбачають побудову фінансових матриць // Сучасні технології управління: електронний науковий журнал. № 3 (39). URL: https://cyberleninka.ru/article/n/analiz-otechestvennyhmetodologicheskih-podhodov-k-razrabotke-finansovoy-strategii-predpriyatiya-predpolagayuschih-postroenie/viewer (дата звернення: 22.07.2020).

6. Дорофеєв М. Л. Матричні методи управління корпоративними фінансами: дис. ... канд. екон. наук: 08.00.10, 08.00.13: 2010: захист: 26.05.2010 / наук.кер. Лісіцина К. В. М.: РЕА ім.Г.В. Плеханова, 2010. 139 с.

7. Воробйов А. В. Вітчизняні методологічні підходи до розробки фінансової стратегії підприємства (генезис і аналіз) // Фінанси і кредит. 2011. № 16 (448). С. 20-27. 1998. $191 \mathrm{c}$.

8. Єфремов В. С. Стратегія бізнесу. Концепції та методи планування: навч. посібник. М.: «Финпрес»,

9. Kalaman O., Savenko I., Dolynska O. Conceptual positions of enterprise strategy functioning // Food Industry Economics. 2019. Vol.11, Issue 3. P. 50-58. doi: 10.15673/fie.v11i3.1461

10. Каламан О. Б. Основні складові концепції управління ефективністю діяльності підприємства. Бізнес, інновації, менеджмент: проблеми та перспективи: зб. тез доп. І Міжнарод. наук.-практ. конф., 23 квіт. 2020 р. Київ: КПІ ім. Ігоря Сікорського, Вид-во «Політехніка», 2020. С. 44-45.

Стаття надійшла 2.08.2020

Стаття прийнята до друку 16.08.2020

Доступно в мережі Internet 15.10.2020

Цитування згідно ДСТУ 8302:2015

Kalaman O., Purtskhvanidze O., Levchuk Yu. Methodology formation of enterprise financial strategy on the basis of existing models analysis // Food Industry Economics. 2020. Vol.12, issue 3. P. 33-41. doi: 10.15673/fie.v12i3.1814

Cite as APA style citation

Kalaman, O., Purtskhvanidze, O. \& Levchuk, Yu. (2020). Methodology formation of enterprise financial strategy on the basis of existing models analysis. Food Industry Economics, 12(3), 33-41. doi: 10.15673/fie.v12i3.1814 